\section{Marigold Cultivars Vary in Susceptibility to Iron Toxicity}

\author{
Joseph P. Albano ${ }^{1}$ and William B. Miller ${ }^{2}$ \\ Department of Horticulture, Clemson University, Clemson, SC 29634-0375
}

Additional index words. plant nutrition, Tagetes erecta, bronze speckle, Fe-DTPA

Abstract. The susceptibility of seven African marigold (Tagetes erecta L.) cultivars to iron toxicity was assessed. Plants were grown in a greenhouse in a soilless medium and FeDTPA was incorporated into the nutrient solution at either $0.018 \mathrm{mmol} \cdot \mathrm{L}^{-1}$ (low) or 0.36 $\mathbf{m m o l} \cdot \mathrm{L}^{-1}$ (high). Symptoms of Fe toxicity (bronze speckle disorder in marigold characterized by chlorotic and necrotic speckling and downward leaf cupping and curling) developed only in the high-Fe treatment. The concentration of $\mathrm{Fe}$ in leaves in the high-Fe treatment was 5.6 and 1.7 times as great as in the low-Fe treatment for 'Orange Jubilee' and 'Discovery Orange', respectively. Based upon the percentage of plants affected and leaf symptom severity, relative cultivar susceptibility to Fe toxicity was Orange Jubilee $>$ First Lady $>$ Orange Lady $>$ Yellow Galore $>$ Gold Lady $>$ Marvel Gold $>$ Discovery Orange. Chemical names used: ferric diethylenetriaminepentaacetic acid, disodium salt dihydrate (Fe-DTPA).

Marigolds are popular annuals used in the landscape and as potted plants, providing numerous variations in plant size, habit, and flower type. The most commonly grown marigolds include cultivars of Tagetes patula L. (French marigold) and Tagetes erecta (African marigold). Plants of $T$. patula are generally less than $45 \mathrm{~cm}$ in height, with small single, double, or crested flowers $(5-8 \mathrm{~cm})$ that range from orange to red. Plants of $T$. erecta and hybrids of $T$. erecta and $T$. patula are up to $90 \mathrm{~cm}$ in height, with double, orange or yellow carnation-like flowers that may exceed $8 \mathrm{~cm}$ in diameter.

During production of African marigolds, a disorder called bronze speckle (Albano et al., 1996) can develop. The disorder is characterized by a chlorotic and bronze-brown necrotic speckling, and downward leaflet curling. Initially, damage is similar to that caused by spider mite feeding. The bronze speckle disorder is caused by excess levels of Fe and possibly $\mathrm{Mn}$ in leaf tissue (Albano et al., 1996; Biernbaum et al., 1988; Ventanovetz and Knauss, 1989).

Factors that increase the level of soluble Fe in media (i.e., fertilizer formulation, water

Received for publication 8 Dec. 1997. Accepted for publication 7 July 1998. Technical contribution No. 4439 of the South Carolina Agricultural Experiment Station. We thank William C. Bridges, Jr. for consultation in this research, and William D. Henriques for technical assistance. This research was supported in part by The Fred C. Gloeckner Foundation and the Clemson Univ. Ornamental Horticulture Competitive Grants Program. Use of trade names does not imply endorsement of the products named nor criticism of similar ones not named. The cost of publishing this paper was defrayed in part by the payment of page charges. Under postal regulations, this paper therefore must be hereby marked advertisement solely to indicate this fact.

'Research Associate.

${ }^{2}$ Professor. Current address: Department of Floriculture and Ornamental Horticulture, Cornell University, Ithaca, NY 14853. alkalinity, and medium $\mathrm{pH}$ ) increase the probability of developing bronze speckle (Albano et al., 1996; Bailey, 1996; Carlson, 1988). As the $\mathrm{N}$ concentration of a complete soluble fertilizer increases, the concentration of the other nutrients, including $\mathrm{Fe}$, increases proportionally. Previous work has indicated that the form of applied $\mathrm{Fe}$ (chelated vs. salt) also has a direct effect on the level of soluble (leachable) $\mathrm{Fe}$ in media, with chelated forms resulting in higher levels of soluble Fe (Albano et al., 1996).

Cultivars within a species can vary in tolerance to Fe toxicity stress (Foy et al., 1978; Harbaugh, 1995; Ramirez and Lang, 1997). In a previous study, 'First Lady' and 'Voyager' marigolds treated with excess Fe varied in asymptomatic and symptomatic leaf Fe concentrations (Albano et al., 1996). Therefore, the objective of this study was to determine the response of seven African marigold cultivars to Fe toxicity. Foliar Mn was also determined, as African marigolds are particularly susceptible to Mn toxicity as well (Biernbaum et al., 1988).

\section{Materials and Methods}

Growing conditions. The African marigold cultivars Discovery Orange (dwarf); First Lady, Gold Lady, Marvel Gold, Orange Lady, Yellow Galore (semidwarf), and Orange Jubilee (hedge) were sown in Fafard 3-B (Fafard, Anderson, S.C.) soilless medium composed of sphagnum peat moss, processed bark, perlite, and vermiculite. Seeds were sown directly into six-cell grow-packs $\left(40 \mathrm{~cm}^{3}\right.$ per cell) in a greenhouse with heating/venting temperatures of $18 / 29^{\circ} \mathrm{C}$. Long-day conditions were provided with supplemental lighting from very high output (VHO) fluorescent lamps between 2200 to $0200 \mathrm{HR}$. A pack of six plants constituted a single replication, and six replications of each treatment and cultivar combination were arranged in a completely randomized design. Iron (Fe-DTPA) treatments of 0.018 $\mathrm{mmol} \cdot \mathrm{L}^{-1}\left(1 \mathrm{mg} \cdot \mathrm{L}^{-1} \mathrm{Fe}\right.$, low $)$ or $0.36 \mathrm{mmol} \cdot \mathrm{L}^{-}$ ${ }^{1}\left(20 \mathrm{mg} \cdot \mathrm{L}^{-1} \mathrm{Fe}\right.$, high) were incorporated into a base nutrient solution, prepared in distilleddeionized water, described previously (Albano and Miller, 1996). Treatments began $15 \mathrm{~d}$ after sowing at emergence of first true-leaf pairs, at which time plants were thinned to one plant per cell. Nutrient solutions $(250 \mathrm{~mL}$ per six cell pack) were applied directly to the media (leaching fraction, 15\% to 25\%) at each irrigation, avoiding any application to foliage.

Visual evaluations of symptom type (e.g., chlorotic speckling, necrotic speckling, or leaf curl) and severity were recorded daily for each plant from treatment initiation to harvest. Plant height was measured from the cotyledonary node to the shoot apex $34 \mathrm{~d}$ after initiating treatments, and three plants from a pack (replication) were harvested for tissue dry weight and elemental analysis. Leaves were classified as symptomatic if any visual symptoms were present, regardless of severity. All remaining leaves were classified as asymptomatic. For mineral analysis, leaf tissue was washed, dried, ashed, and prepared for atomic absorption spectrophotometry as described previously (Albano et al., 1996). Two similar experiments, independently designed, were conducted in the same greenhouse simultaneously.

Statistics. Data were analyzed by analysis of variance to determine the effects of experiment, cultivar, and Fe treatments, and the significance of interaction between these factors. Calculations were performed with the general linear model (GLM) procedure of SAS (SAS Institute, Cary, N.C.). Means were separated and planned comparisons were made using LSD or pairwise $t$ tests.

\section{Results and Discussion}

Disorder development. Iron toxicity symptoms developed only in the high-Fe treatment, and were characterized by patches of interveinal chlorosis, bronze-necrotic speckling, and downward leaf curling, consistent with the symptoms of $\mathrm{Fe}$-induced bronze speckle disorder (Albano et al., 1996). Symptoms began to appear $4 \mathrm{~d}$ after initiating treatments in 'Orange Lady'. 'Discovery Orange' was the last cultivar to develop symptoms of bronze speckle at $12 \mathrm{~d}$ after initiating treatments. There was no experiment by cultivar interaction, and therefore data were pooled for analyses. 'Orange Jubilee' and 'Discovery Orange' plants were the greatest and least severely affected plants at harvest, respectively (Table 1). 'Orange Jubilee' and 'Discovery Orange' also had the most and least plants affected at harvest at $99 \%$ and $24 \%$, respectively (Table 1 ).

Plant growth. Neither plant height nor leaf number was affected by Fe treatment in either experiment. Mean plant height for all cultivars was $0.8 \mathrm{~cm}$ greater in Expt. 2 than in Expt. 1, but experiment by cultivar interaction for plant height was nonsignificant; the data were pooled for both experiments. The tallest and shortest cultivars were Orange Jubilee $(31.8 \mathrm{~cm})$ and Discovery Orange $(7.0 \mathrm{~cm})$, respectively (Table 
Table 1. Percentage of plants affected with bronze speckle, and symptom severity rating for the high-Fe $\left(0.36 \mathrm{mmol} \cdot \mathrm{L}^{-1} \mathrm{Fe}-\mathrm{DTPA}\right)$ treatment, plant height and leaf dry weight as an average of both the high-Fe and low-Fe $\left(0.018 \mathrm{mmol} \cdot \mathrm{L}^{-1} \mathrm{Fe}-\mathrm{DTPA}\right)$ treatments, and total leaf Fe and Mn concentration for seven marigold cultivars as affected by Fe-DTPA concentration in the nutrient solution. Data are means for Expts. 1 and 2.

\begin{tabular}{|c|c|c|c|c|c|c|c|c|}
\hline \multirow[b]{2}{*}{ Cultivar } & \multirow{2}{*}{$\begin{array}{c}\text { Affected } \\
\text { plants }(\%)^{2}\end{array}$} & \multirow{2}{*}{$\begin{array}{l}\text { Symptom } \\
\text { severity }^{x}\end{array}$} & \multirow{2}{*}{$\begin{array}{l}\text { Height } \\
(\mathrm{cm})\end{array}$} & \multirow{2}{*}{$\begin{array}{c}\text { Leaf DW } \\
(\mathrm{g})\end{array}$} & \multicolumn{2}{|c|}{$\mathrm{Fe}\left(\mu \mathrm{g} \cdot \mathrm{g}^{-1}\right)$} & \multicolumn{2}{|c|}{$\mathrm{Mn}\left(\mu \mathrm{g} \cdot \mathrm{g}^{-1}\right)$} \\
\hline & & & & & Low & High & Low & High \\
\hline Orange Jubilee & $99 a^{y}$ & $3.5 \mathrm{a}$ & $31.8 \mathrm{a}$ & $1.12 \mathrm{a}$ & $120 \mathrm{~d}$ & $666 b^{* * *}$ & $95 \mathrm{c}$ & $98 b^{N S}$ \\
\hline Gold Lady & $54 \mathrm{bc}$ & $2.1 \mathrm{~cd}$ & $14.5 b$ & $0.94 \mathrm{~b}$ & $286 \mathrm{a}$ & $828 \mathrm{a}^{* * *}$ & $138 \mathrm{~b}$ & $139 \mathrm{a}^{\mathrm{NS}}$ \\
\hline Yellow Galore & $61 \mathrm{~b}$ & $2.2 \mathrm{c}$ & $14.4 \mathrm{~b}$ & $0.89 \mathrm{~b}$ & $157 \mathrm{~cd}$ & $364 \mathrm{~d}^{* * *}$ & $89 \mathrm{~d}$ & $88 b^{\mathrm{NS}}$ \\
\hline Orange Lady & $71 \mathrm{~b}$ & $2.5 \mathrm{bc}$ & $14.3 \mathrm{bc}$ & $0.92 b$ & $229 b$ & $753 \mathrm{ab}^{\text {**** }}$ & $151 \mathrm{a}$ & $144 \mathrm{a}^{\mathrm{NS}}$ \\
\hline Marvel Gold & $40 c$ & $1.9 \mathrm{~d}$ & $13.3 \mathrm{bc}$ & $0.88 \mathrm{~b}$ & $180 \mathrm{c}$ & $548 \mathrm{c}^{* * *}$ & $103 \mathrm{c}$ & $127 \mathrm{a}^{* * *}$ \\
\hline First Lady & $71 \mathrm{~b}$ & $2.6 \mathrm{~b}$ & $13.1 \mathrm{c}$ & $0.75 \mathrm{c}$ & $255 \mathrm{ab}$ & $679 b^{* * *}$ & $137 \mathrm{~b}$ & $131 \mathrm{a}^{\mathrm{NS}}$ \\
\hline Discovery Orange & $24 \mathrm{~d}$ & $1.4 \mathrm{~d}$ & $7.0 \mathrm{~d}$ & $0.57 \mathrm{~d}$ & $241 \mathrm{~b}$ & $406 \mathrm{~d}^{* *}$ & $157 \mathrm{a}$ & $132 \mathrm{a}^{* * *}$ \\
\hline
\end{tabular}

${ }^{2} \mathrm{n}=72$ plants per cultivar.

${ }^{y}$ Mean separation within columns by LSD, $P \leq 0.05$.

${ }^{\mathrm{x}} 1$ = normal, 2 = chlorotic speckling, $3=$ chlorotic and necrotic speckling, $4=$ chlorotic and necrotic speckling, and downward leaf cupping and curling.

NS, ${ }^{*},{ }^{* *},{ }^{* * *}$ Nonsignificant or significantly different from low Fe-DTPA concentration at $P=0.05,0.01$, and 0.001 , respectively, by pairwise $t$ test.

1). The semidwarf cultivars ranged in height from $14.5 \mathrm{~cm}$ for 'Gold Lady' to $13.1 \mathrm{~cm}$ for 'First Lady' (Table 1), and the average number of true-leaf pairs produced by all cultivars and in both treatments ranged from six to seven (data not shown).

Leaf dry weight per plant was not affected by $\mathrm{Fe}$ treatment in either experiment, but the mean value for all cultivars was greater in Expt. 2 than in Expt. 1 (0.89 vs. 0.84 g per plant, respectively). Experiment by cultivar interaction was nonsignificant, therefore the data for both experiments were pooled. 'Orange Jubilee' and 'Discovery Orange' had the greatest and least dry weight (Table 1). Leaf dry weight for the semidwarf cultivars ranged from $0.94 \mathrm{~g}$ for 'Gold Lady' to $0.75 \mathrm{~g}$ for 'First Lady' (Table 1).

Leafiron and manganese. Leaf Fe concentration was similar in both experiments, so data were combined for all analyses (Table 1). At the low application rate, Fe ranged from 120 to $286 \mu \mathrm{g} \cdot \mathrm{g}^{-1} \mathrm{Fe}$ (Table 1 ), indicating that cultivars vary in capacity to take up and/or translocate Fe to shoots. Similar observations have been made in $\mathrm{Fe}$ toxicity cultivar trials conducted on potted Pentas lanceolata Benth. (Harbaugh, 1995) and Schlumbergera sp. (Ramirez and Lang, 1997).

Fe uptake and translocation within the plant is influenced by several factors, including nutrient antagonisms and $\mathrm{pH}$ (Reed, 1996; Warden and Reisnauer, 1991), temperature and light (Brown et al., 1979; Lahav and Turner, 1984); and Fe-efficiency reactions (Bienfait, 1988). In previous work on 'First Lady', however, we found that Fe-efficiency reactions, as determined by $\mathrm{Fe}^{3+}$ root reductase activity, were only induced under Fe deficient conditions (Albano and Miller, 1996).

Mean leaf Fe concentration for all cultivars in the low-Fe and high-Fe treatments (asymptomatic and symptomatic leaf tissue combined) averaged 210 and $606 \mu \mathrm{g} \cdot \mathrm{g}^{-1}$, respectively (Table 1). In the high-Fe treatment, the Fe concentration in asymptomatic and symptomatic leaves averaged 492 and $685 \mu \mathrm{g} \cdot \mathrm{g}^{-1} \mathrm{Fe}$, respectively, over all cultivars (Table 2). No cultivar except Yellow Galore developed symptoms of Fe toxicity at an Fe concentration below $500 \mu \mathrm{g} \cdot \mathrm{g}^{-1}$ (Table 2), consistent with other work indicating that, in general, the critical concentration for $\mathrm{Fe}$ toxicity ranges from 400 to $800 \mu \mathrm{g} \cdot \mathrm{g}^{-1}$ (Biernbaum et al.,

Table 2. Effects of the higher Fe concentration $\left(0.36 \mathrm{mmol} \cdot \mathrm{L}^{-1} \mathrm{Fe}-\mathrm{DTPA}\right)$ on leaf dry weight and on leaf Fe and $\mathrm{Mn}$ concentrations in asymptomatic (Asym) and symptomatic (Sym) tissues of seven marigold cultivars harvested $34 \mathrm{~d}$ after initiating treatments. Data are means for Expts. 1 and 2.

\begin{tabular}{|c|c|c|c|c|c|c|}
\hline \multirow[b]{2}{*}{ Cultivar } & \multicolumn{2}{|c|}{ Leaf DW (g) } & \multicolumn{2}{|c|}{$\mathrm{Fe}\left(\mu \mathrm{g} \cdot \mathrm{g}^{-1}\right)$} & \multicolumn{2}{|c|}{$\operatorname{Mn}\left(\mu \mathrm{g} \cdot \mathrm{g}^{-1}\right)$} \\
\hline & Asym & Sym & Asym & Sym & Asym & Sym \\
\hline Orange Jubilee & $0.04 \mathrm{~d}^{\mathrm{z}}$ & $1.06 \mathrm{a}^{* * * *}$ & $-\ldots y$ & $666 \mathrm{c}$ & $\ldots y$ & $98 b^{x}$ \\
\hline Gold Lady & $0.26 \mathrm{bc}$ & $0.69 \mathrm{~b}^{* * *}$ & $684 \mathrm{a}$ & $919 a^{* *}$ & $127 \mathrm{ab}$ & $147 \mathrm{a}$ \\
\hline Yellow Galore & $0.17 \mathrm{~cd}$ & 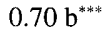 & $360 \mathrm{~b}$ & $367 \mathrm{~d}^{\mathrm{ss}}$ & $87 \mathrm{c}$ & $89 \mathrm{~b}$ \\
\hline Orange Lady & $0.14 \mathrm{~cd}$ & $0.79 b^{* * *}$ & $645 \mathrm{a}$ & $825 a b^{* *}$ & $152 \mathrm{a}$ & $139 a$ \\
\hline Marvel Gold & $0.41 \mathrm{ab}$ & $0.51 \mathrm{c}^{\mathrm{NS}}$ & $413 \mathrm{~b}$ & $696 \mathrm{bc}^{* * *}$ & $121 \mathrm{~b}$ & $134 \mathrm{a}$ \\
\hline First Lady & $0.17 \mathrm{~cd}$ & $0.66 \mathrm{~b}^{* * *}$ & $495 b$ & $818 a b^{* * * *}$ & $114 b$ & $144 \mathrm{a}$ \\
\hline Discovery Orange & $0.51 \mathrm{a}$ & $0.10 \mathrm{~d}^{* * *}$ & $357 \mathrm{~b}$ & $504 \mathrm{~d}^{*}$ & $128 \mathrm{ab}$ & $140 \mathrm{a}$ \\
\hline
\end{tabular}

${ }^{\mathrm{z}}$ Mean separation within columns by LSD, $P \leq 0.05$.

'Insufficient amount of tissue for analysis.

${ }^{x}$ No mean separation between Asym and Sym because of insufficient tissue for analysis.

ns, ${ }^{* *}, * * *$ Nonsignificant or significantly different from Asym at $P=0.01$ and 0.001 , respectively, by pairwise $t$ test.

1988; Choi et al., 1996). In a previous study conducted in a controlled-environment growth chamber, however, we found that the critical concentration of $\mathrm{Fe}$ to cause toxicity can vary considerably with growing conditions and leaf age (Albano et al., 1996). Indeed, in the present study we did not find a correlation between $\mathrm{Fe}$ concentration and symptom severity (Tables 1 and 2). In general, these observations support the view that the most common physiological attribute of Fe toxicity is an increase in both $\mathrm{Fe}$ uptake and transport to shoots (Foy et al., 1978). However, they also show that cultivars can vary considerably in susceptibility to the disorder.

Leaf Fe concentration ranged from 357 to $684 \mu \mathrm{g} \cdot \mathrm{g}^{-1}$ in asymptomatic leaf tissue, and from 367 to $919 \mu \mathrm{g} \cdot \mathrm{g}^{-1}$ in symptomatic leaf tissue (Table 2). In all cultivars except Yellow Galore the Fe concentration was higher in symptomatic than in asymptomatic leaf tissue (Table 2).

Levels of $\mathrm{Fe}$ in symptomatic leaf tissue of 'Yellow Galore' were similar to those in asymptomatic leaf tissue (Table 2). Localized analysis of lesions vs. whole leaf analysis of symptomatic leaves, as was done in this study, may help explain the disorder that developed in 'Yellow Galore'. This cultivar may differ in the production of ferritin, which is the main $\mathrm{Fe}$-storage protein in plants. Ferritin has been proposed as a mechanism of tolerance to $\mathrm{Fe}$ toxicity (Verkleij and Schat, 1990). Ferritin is found in plastids of photosynthetic tissue and root meristems, and serves as a cellular $\mathrm{Fe}$ buffer (Thiel, 1987; van der Mark et al., 1981). Ferritin synthesis is regulated by $\mathrm{Fe}$; a cellular influx of chelatable Fe causes the production of the protein through transcriptional control of the ferritin gene by an iron-responsive element binding protein (Harford and Klausner, 1990; Proudhon et al., 1989).

Leaf $\mathrm{Mn}$ concentration was similar for both experiments, therefore data were combined for all analyses. For all cultivars except Marvel Gold and Discovery Orange, Fe level did not affect leaf Mn concentration (asymptomatic and symptomatic tissue combined) (Table 1). In 'Marvel Gold', Mn concentration was greater in the high-Fe treatment, but the reverse was true for 'Discovery Orange' (Table 1). 'Orange Lady' and 'Yellow Galore' had the highest and the lowest leaf Mn concentrations, respectively, of all cultivars in both the low-Fe and high-Fe treatments (Table 1). In the high-Fe treatment, there was no difference in $\mathrm{Mn}$ concentration between asymptomatic and symptomatic leaf tissue (Table 2). Leaf $\mathrm{Mn}$ concentrations ranged from 87 to 152 $\mu \mathrm{g} \cdot \mathrm{g}^{-1}$ in asymptomatic leaves, and from 89 to $147 \mu \mathrm{g} \cdot \mathrm{g}^{-1}$ in symptomatic leaves (Table 2).

In summary, based on the number of plants affected, leaf symptom severity, and symptomatic leaf tissue dry weight, the susceptibility of the cultivars to Fe toxicity varied considerably in this study. In general, more severe symptoms were associated with a greater percentage dry weight of symptomatic leaf tissue and a greater percentage of plants affected with the disorder. Order of susceptibility using these criteria was 'Orange Jubilee' > 'First Lady' > 'Orange Lady' > 'Yellow Galore' > 'Gold Lady' > 'Marvel Gold' > 'Discovery Orange'. The foliar Fe concentration in plants 
supplied with a concentration of Fe-chelate typically used in commercial greenhouse and nursery operations varied greatly with cultivar, as did the foliar Fe concentration at which toxicity occurred. Growers should be aware that when interpreting data from foliar analysis, African marigold cultivars differ in both foliar Fe concentration and susceptibility to $\mathrm{Fe}$ toxicity.

\section{Literature Cited}

Albano, J.P. and W.B. Miller. 1996. Iron deficiency stress influences physiology of iron acquisition in marigold (Tagetes erecta L.). J. Amer. Soc. Hort. Sci 121:438-441.

Albano, J.P., W.B. Miller, and M.C. Halbrooks. 1996. Iron toxicity stress causes bronze speckle, a specific physiological disorder of marigold (Tagetes erecta L.). J. Amer. Soc. Hort. Sci. 121:430-437.

Bailey, D.A. 1996. Alkalinity, pH, and acidification, p. 69-91. In: D.W. Reed (ed.). Water, media, and nutrition for greenhouse crops. Ball Publishing, Batavia, Ill.

Bienfait, H.F. 1988. Mechanisms in Fe-efficiency reactions of higher plants. J. Plant Nutr. 11:605-629.
Biernbaum, J.A., W.H. Carlson, C.A. Shoemaker, and R. Heins. 1988. Low pH causes iron and manganese toxicity. Greenhouse Grower 6(3):92-93, 96-97.

Brown, J.C., C.D. Foy, J.H. Bennett, and M.N. Christiansen. 1979. Two light sources differentially affected ferric iron reduction and growth of cotton. Plant Physiol. 63:692-695.

Carlson, W.H. 1988. The secret culprit: pH. Greenhouse Grower 6(1):12-13.

Choi, J., C. Pak, and C.W. Lee. 1996. Micronutrient toxicity in French marigold. J. Plant Nutr. 19:901-916.

Foy, C.D., R.L. Chaney, and M.C. White. 1978. The physiology of metal toxicity in plants. Annu. Rev. Plant Physiol. 29:511-566.

Harbaugh, B.K. 1995. Iron toxicity in Pentas lanceolata. HortTechnology 5:306-307.

Harford, J.B. and R.D. Klausner. 1990. Coordinate post-transcriptional regulation of ferritin and transferrin receptor expression: The role of regulated RNA-protein interaction. Enzyme 44:28-41.

Lahav, E. and D.W. Turner. 1984. The effect of temperature on the iron content of banana suckers. J. Plant Nutr. 7:725-731.

Proudhon, D., J. Briat, and A. Lescure. 1989. Iron induction of ferritin synthesis in soybean cell suspensions. Plant Physiol. 90:586-590.
Ramirez D. and H.J. Lang. 1997. Effect of applied iron concentration on growth and phyllocade marginal chlorosis of holiday cactus (Schlumbergera sp.). J. Amer. Soc. Hort. Sci. 122:438-444.

Reed, D.W. 1996. Micronutrient nutrition, p. 171195. In: D.W. Reed (ed.). Water, media, and nutrition for greenhouse crops. Ball Publishing, Batavia, Ill.

Theil, E.C. 1987. Ferritin: Structure, gene regulation, and cellular function in animals, plants, and microorganisms. Annu. Rev. Biochem. 56:289315.

van der Mark, F., T. de Lange, and H.F. Bienfait. 1981. The role of ferritin in developing primary bean leaves under various light conditions. Planta 153:338-342.

Ventanovetz, R.P. and J.F. Knauss. 1989. Iron toxicity: What should you know! Benchmarks 4(5):3-4. Grace, Cambridge, Mass.

Verkleij, J.A. and H. Schat. 1990. Mechanisms of heavy metal tolerance in higher plants, p. 180189. In: A.J. Shaw (ed.). Heavy metal tolerance in plants: Evolutionary aspects. CRC Press, Boca Raton, Fla.

Warden, B.T. and H.M. Reisenauer. 1991. Manganese-iron interactions in the plant-soil system. J. Plant Nutr. 14:7-30. 